\title{
Caupolicana in Central America (Hymenoptera, Colletidae, Diphaglossinae)
}

\author{
Charles D. Michener, Michael S. Engel
}

Division of Entomology, Natural History Museum, and Department of Ecology \& Evolutionary Biology, University of Kansas, Lawrence, USA

† urn:lsid:zoobank.org:author:5A77AFE7-0201-442C-A57B-5DF5CAC6C776

¥urn:lsid:zoobank.org:author:3714A7FF-E19E-495A-AAF9-98D2F597B757

Corresponding author: Charles D. Michener (michener@ku.edu)

Academic editor: Michael Ohl | Received 2 December 2008 | Accepted 20 January 2009 | Published 16 February 2009

urn:lsid:zoobank.org:pub:D1117595-OB9B-4731-B745-2F50C9E70E56

Citation: Michener CD, Engel MS (2009) Caupolicana in Central America (Hymenoptera, Colletidae, Diphaglossinae). ZooKeys 5: 53-64. doi: 10.3897/zookeys.5.76

\begin{abstract}
Caupolicana (Zikanapis) wileyi sp. n. from Guatemala is described. New locality records are noted for other species, and the hitherto unknown female of $C$. $(Z$.) rozenorum Michener, Engel, and Ayala from Guatemala is described. A key for the identification of Central American Caupolicana is provided.
\end{abstract}

\section{Keywords}

Hymenoptera, Apoidea, Colletidae, Diphaglossinae, Caupolicana, Zikanapis, C. wileyi, C. rozenorum, taxonomy, new species, identification key

\section{Introduction}

The large and conspicuous bees of the genus Caupolicana, subgenus Zikanapis, that occur in tropical America are probably all crepuscular or nocturnal and are therefore rather rarely taken by bee collectors. Revisional studies of this group of about a dozen species are those of Moure (1964) for South America and Michener et al. (2003) for Central America. Below we describe another species from Central America (Guatemala), Caupolicana (Zikanapis) wileyi sp. n., raising the number of species known from the region to four, and record new data for certain other species.

All Central American species of Caupolicana belong to the subgenus (or genus, depending on the classification) Zikanapis Moure, 1945. Distinctive features of Zikanapis 
were described by Moure (1945) and Michener (1966), and summarized by Michener (2007). Minor modifications of these characterizations are noted in the present study, as follows: In $C$. $(Z$.) wileyi, the broad median apical projection of the sixth metasomal sternum of the male has an apical concavity that is rounded, not V-shaped. Furthermore, the dense, minute setae of the broad areas of the ventrolateral parts of the second through the fourth metasomal terga (and to a lesser extent, the fifth metasomal tergum) are not erect but are decumbent and directed upward and slightly posteriorly.

Our present work was stimulated by Dr. James R. Wiley who sent us for study a small collection of mostly Guatemalan Caupolicana from the Entomology Museum, Florida State Collection of Arthropods, Gainesville, Florida. The collector of much of this material, Dr. J.B. Heppner, has reported to Dr. Wiley that these bees were abundant at a black light (UV) trap. Many moth scales are on the specimens, no doubt transferred to the bees when struggling together with moths in the trap. These findings support the view that these bees are nocturnal or crepuscular. Additional Guatemalan material was received from Dr. Enio Cano of the Universidad del Valle de Guatemala. Labels on some of the specimens of $C$. (Z.) rozenorum Michener, Engel \& Ayala indicate that they were taken at lights.

Abbreviations used below are T and S for terga(um) and sterna(um), such that, for example, T1 is the first metasomal tergum. The abbreviation OD is the horizontal diameter of the anterior ocellus, used to measure various other cephalic structures or distances between them. Collections in which specimens are housed are abbreviated as follows: KSEM, Division of Entomology, Natural History Museum, University of Kansas, Lawrence, Kansas, USA; FSCA, Florida State Collection of Arthropods, Florida Department of Agriculture, Gainesville, Florida, USA; UVGC, Universidad del Valle de Guatemala, Guatemala City, Guatemala. Photomicrographs were prepared using a Nikon D1x digital camera attached to an Infinity $\mathrm{K} 2$ long-distance microscopic lens.

\section{Key to species of Central American Caupolicana}

The key to species of Central American Caupolicana, below, is based on that of Michener et al. (2003), which contains references to figures that are useful in interpreting the key but are not duplicated here. Accordingly, we encourage use of the key in conjunction with our earlier contribution (Michener et al., 2003). The key below differs from the 2003 version primarily in that $C$. wileyi is included, as is the female of $C$. rozenorum.

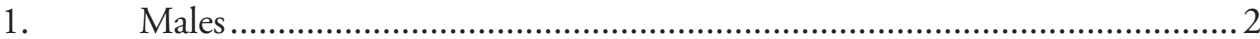

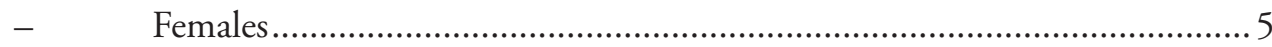

2. Clypeus largely brownish yellow, densely punctate except near lower margin (Guatemala, Mexico) C. clypeata (Smith)

- $\quad$ Clypeus brown or black, concolorous with remainder of head, at least lower half of clypeus with areas having punctures separated by about a puncture width or more of shiny integument 
3. T2 and T3, and to some degree T4, covered with suberect black setae (Guatemala). C. wileyi sp. n.

- T2 to T4 covered with pale brown setae............................................. 4

4. Metatibia little over three times as long as wide, upper and lower margins both convex; legs brownish black (Costa Rica, El Salvador, Guatemala).

C. rozenorum Michener, Engel \& Ayala

- Metatibia nearly 4.5 times as long as wide, lower margin straight, upper margin convex; legs reddish brown, metabasitarsi yellowish dark testaceous (Costa Rica)

C. inbio Michener, Engel \& Ayala

5. Clypeus densely punctate, with erect brown setae, some of them bent at tips, surface of clypeus nearly flat (Guatemala, Mexico) C. clypeata (Smith)

- Clypeus with lower two thirds medially shining, with scattered coarse punctures and other irregularities (Figs. 2, 3), setae not erect, not bent at tips ....6

6. Pile of mesoscutum and mesoscutellum black or nearly so (Figs. 3, 13); setae of posterior half of dorsal surface of T1 dusky or blackish, unlike white or ochraceous hairs of anterior half (Guatemala) C. wileyi sp. n.

- $\quad$ Pile of mesoscutum and mesoscutellum ochraceous (Figs. 1, 2), tips of setae usually brown or blackish; setae of T1 uniformly whitish or orchraceous or dusky setae intermixed on posterior part..... . .7

7. Distance between posterior ocelli distinctly less than 1 OD (Costa Rica)...... C. inbio Michener, Engel \& Ayala - Distance between posterior ocelli subequal to 1 OD (Costa Rica, El Salvador, Guatemala) C. rozenorum Michener, Engel \& Ayala

\section{Systematics}

Caupolicana (Zikanapis) inbio Michener, Engel \& Ayala

Caupolicana (Zikanapis) inbio Michener et al., 2003: 164.

New record. One male from Costa Rica: Cartago Province, Tuís, VII-16-29-1997 (H.L. Dozier) [FSCA].

\section{Caupolicana (Zikanapis) rozenorum Michener, Engel \& Ayala}

(Figs. 1-2)

Caupolicana (Zikanapis) rozenorum Michener et al., 2003: 169.

New records. One male, one female from Guatemala: Guatemala Province: Puerta Parada, IX-5-8-2001 (J. Schuster) [FSCA]; two males, same locality and collector, $1900 \mathrm{~m}, \mathrm{VII}-16-2002$ and XI-6-13-2003 [UVGC]; one female, same locality and collector, 1860 m, IV-11-18-2004 [UVGC]; two females from same locality and collector, 


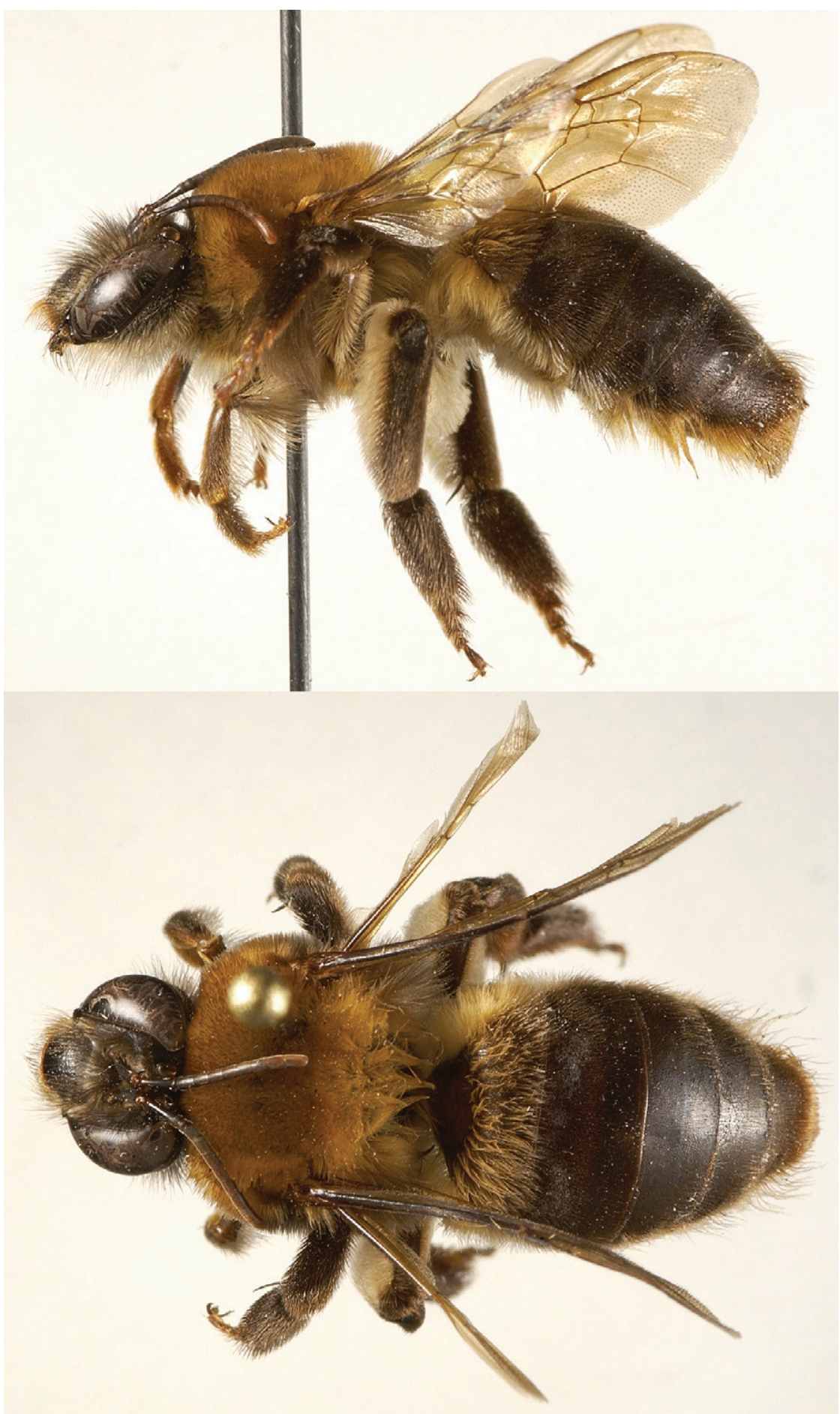

Fig. I. Lateral (above) and dorsal (below) views of female of Caupolicana (Zikanapis) rozenorum Michener, Engel, and Ayala. 
in malaise trap, VIII-25 to IX-1, 2007 [KSEM]. Two females, Suchitepéquez Province: Los Tamales, Volcán Atitlán, 800-1000 m, IX-24-26-2006 (J.B. Heppner) [KSEM]. One male, same province, Santa Barbara, Res. Refuío Quetzal, 1600 m, VI-27-2007 [UVGC]. One male, Baja Verapáz Province: Salama, camino Pantína Santa Rosa, 1700 m, VI-10-15-2007 (Monzón y Camposecu) [UVGC]. One male, San Marcos Province: San Rafael Pie de la Cuesta, camino a aldea El Bojonal, 1600 m, V-24-2005 (J.M. Sierra) [UVGC]; one male, same but camino de Frater-Bojonal, 1600 m, V-26-2006 [UVGC]. One female, Quetzaltenango Province: Palmar Viejo, finca El Faro, 1400 m, III-16-17-1997 (Rodriguez y Taracena) [UVGC]. One female, El Salvador: San Vicente: Volcán San Vicente, finca El Carmen, 1400 m, IX-14-2006, at mercury vapor light (E. Cano and J. Schuster) [UVGC]. One female, Costa Rica: Guanacaste Province: Estación Cacao, 2 km SW of Cerro Cacao, 1100 m, II-7-18-1995 (M. Chinchilla) [FSCA]. One female, same locality, southwest side of Cerro Cacao, 1000-1400 m, March 1988 [KSEM].

Comments. This species was originally described (Michener et al., 2003) on the basis of four males from three different localities in Costa Rica. Two females from one of these localities were considered possibly $C$. rozenorum and their characters were noted. We now have males and females from a locality in Guatemala as listed above. These females appear to be the same species as the females noted in 2003, supporting the tentative association of sexes. Additional females from localities in Guatemala, San Salvador, and Costa Rica were not taken with males. The data for these specimens are listed above.

Comparisons. The following paragraphs list differences between C. rozenorum and C. inbio.

Male: Caupolicana rozenorum and C. inbio are noteworthy because of the very striking difference in the metatibial shape and setation (see above key and figures 21 and 22 in Michener et al., 2003) but near absence of other differences. The differentiating characters other than the metatibia listed in the original description of the male of C. rozenorum are not reliable. The middle flagellar segments of $C$. inbio are sometimes about 1.5 times as long as broad as described for $C$. rozenorum. The punctures on the shining central part of the lower half of the clypeus are more widely scattered in $C$. rozenorum than in the available specimens of $C$. inbio, but the difference is not impressive and intergradation is probable. The integument is generally paler in C. inbio than in C. rozenorum; thus the flagellum is brown to blackish, darker above than below, in $C$. inbio whereas it is blackish, dark brown below, in C. rozenorum. Moreover, the legs are brown with the metabasitarsus yellowish in $C$. inbio, whereas the legs including the metabasitarsus are dark brown in C. rozenorum. The setae on the outer surfaces of the meso- and metatibiae are mostly pale in $C$. inbio, mostly somewhat dusky in $C$. rozenorum, the darkness varying with the angle of illumination. The supposed difference in dark apices of the mesosomal pile does not exist. An additional apparent difference is in the ocellocular distance, which, although given as $0.15 \mathrm{OD}$ for both species in the original descriptions, seems to be less in $C$. rozenorum; this apparently does not apply to all specimens.

Female: Length 17-21 mm (averaging slightly smaller than C. inbio); forewing length 11-13 mm. Upper interorbital distance about 3 OD; lower interorbital distance 
about 5 OD; interocellar distance about $1 \mathrm{OD}$; ocellocular distance about $0.5 \mathrm{OD}$; other measurements approximately as recorded for $C$. inbio. Clypeus broadly convex without weak longitudinal depression on each side of weak median longitudinal area as found in C. inbio. Inner metatibial spur with 17 or 18 large teeth (not counting small basal teeth and preapical tooth sometimes present). Integument including metatarsus largely black but pro- and mesofemora and tibiae with brownish areas; pygidial plate medially dark brown. Setae of tarsi largely fuscous although with yellowish reflections. Pile of mesosomal dorsum and T1 usually darker than in C. inbio because of black or dusky apical parts of setae.

\section{Caupolicana (Zikanapis) wileyi Michener \& Engel, sp. n.} urn:lsid:zoobank.org:act:37C65F37-FFBC-4A19-B744-4D15B4CC9EB1 (Figs. 3-13)

Type material. Holotype male and three male paratypes, Guatemala: Baja Verapáz Province: Quetzal Res., "Los Ranchitos", 1680-1750 m, 10-15 June, 2007 (J.B. Heppner) [KSEM, one paratype at FSCA].

Additional material. Two females, same data as holotype [KSEM]. Two females, same but "Los Rancheros", 1650 m, 21-23 September, 2006 [KSEM, FSCA]. One female, Guatemala: Escuíntla Province: La Gomera, V-13-2001 (A. Gomalez) [UVGC].

Diagnosis. Among similar species of the subgenus Zikanapis, such as $C$. inbio and C. rozenorum, the male of $C$. wileyi differs by the dense suberect black setae of $\mathrm{T} 2$ and $\mathrm{T} 3$ and to some degree of T4, while the female differs from the others by the black or
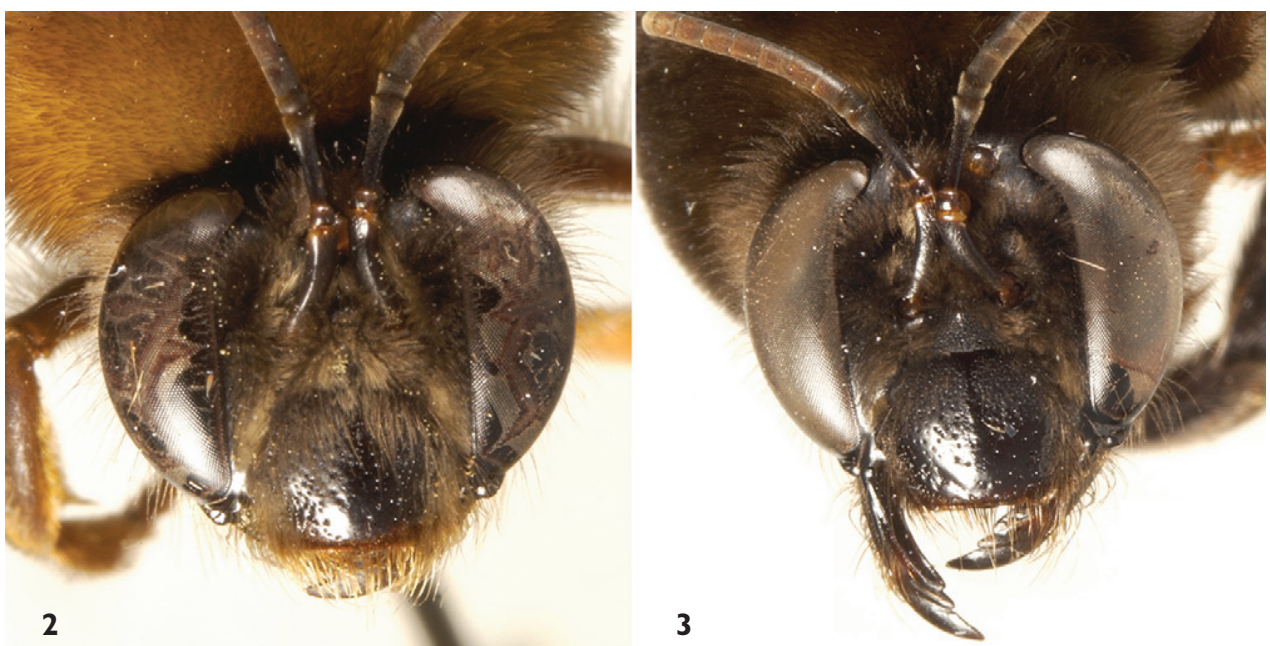

Figs. 2-3. Facial aspects of Guatemalan Caupolicana females (not to same scale). 2) Caupolicana (Zikanapis) rozenorum Michener, Engel \& Ayala. 3) C. (Z.) wileyi sp. n. 


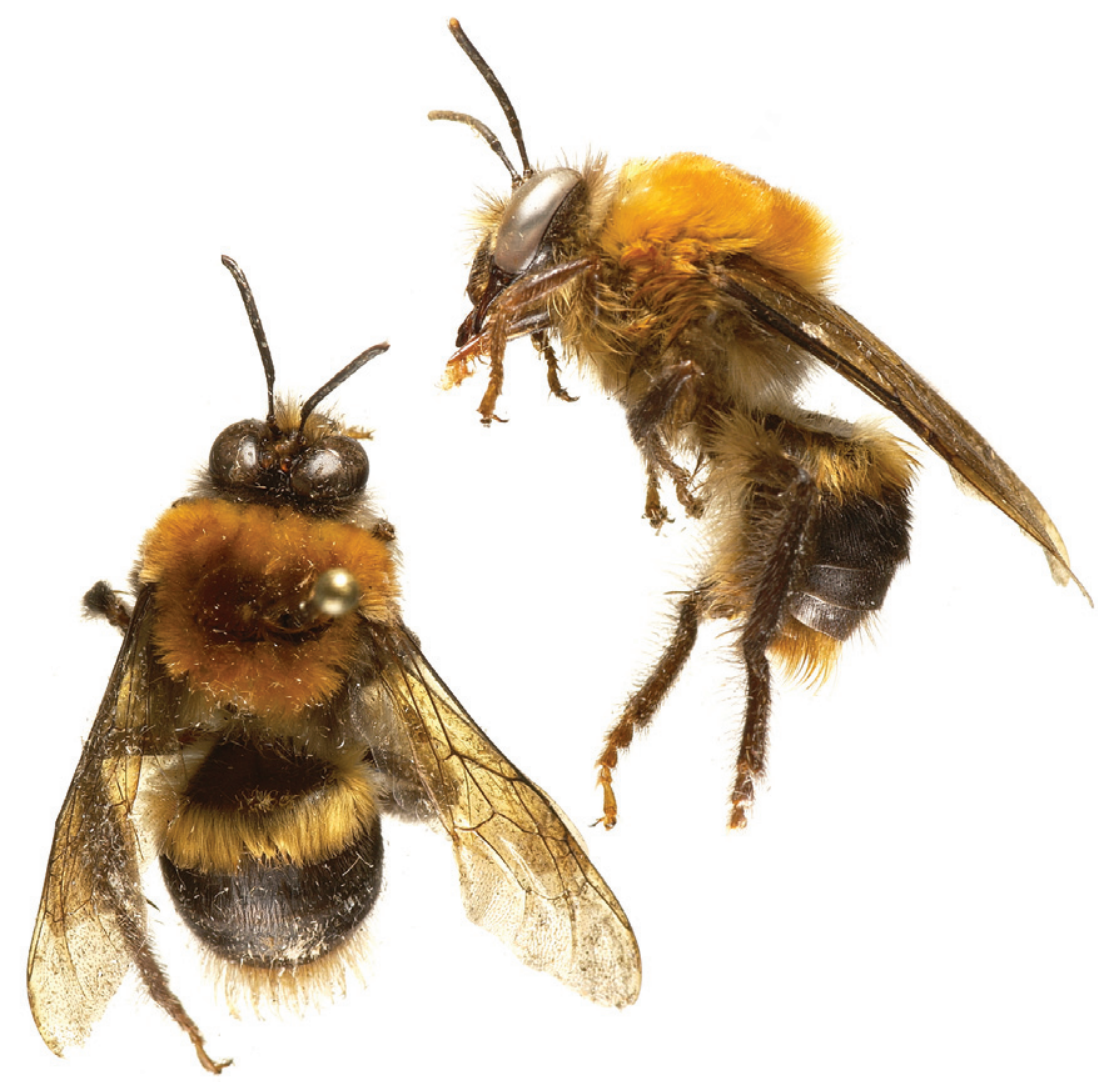

Fig. 4. Lateral (above, right) and dorsal (below, left) views of male of Caupolicana (Zikanapis) wileyi sp. n.

in some areas blackish pile of the mesosomal dorsum and T1. Metatibia of male about 4.8 times as long as greatest breadth, distal half parallel sided. S8 of male with midapical process nearly parallel sided, not slender basally as in C. inbio.

Description. Male: Length $18 \mathrm{~mm}$ (17 mm in some paratypes); forewing length (including tegula) $15 \mathrm{~mm}$. Upper interorbital distance $2.17 \mathrm{OD}$; lower interorbital distance 4.3 OD; interocellar distance $0.5 \mathrm{OD}$; ocellocular distance $0.15 \mathrm{OD}$; ocelloccipital distance 1.5 OD (Fig. 5); length of scape 2.2 OD. Otherwise agreeing with description of C. inbio (Michener et al., 2003) except as follows: First flagellar segment markedly longer than scape (Fig. 7); second flagellar segment broader than long; metatibia in lateral (broadest) view about 4.8 times as long as greatest breadth (Fig. 8), distal half parallel sided, lower margin gently convex medially but distal half straight, upper margin nearly straight but proximal and distal parts feebly convex; genitalia and S7 (Figs. 9, 11, 12) essentially as in C. inbio (Michener et al., 2003: figs. 13, 15, 16); S8 with midapical process nearly parallel sided (Fig. 10), not so slender basally as in $C$. inbio (Michener et al., 2003: fig. 14).

Punctation as in C. inbio, lower midapical part of shiny area of clypeus with a few, scattered, large punctures (true also for some C. inbio, contrary to description). Base of 


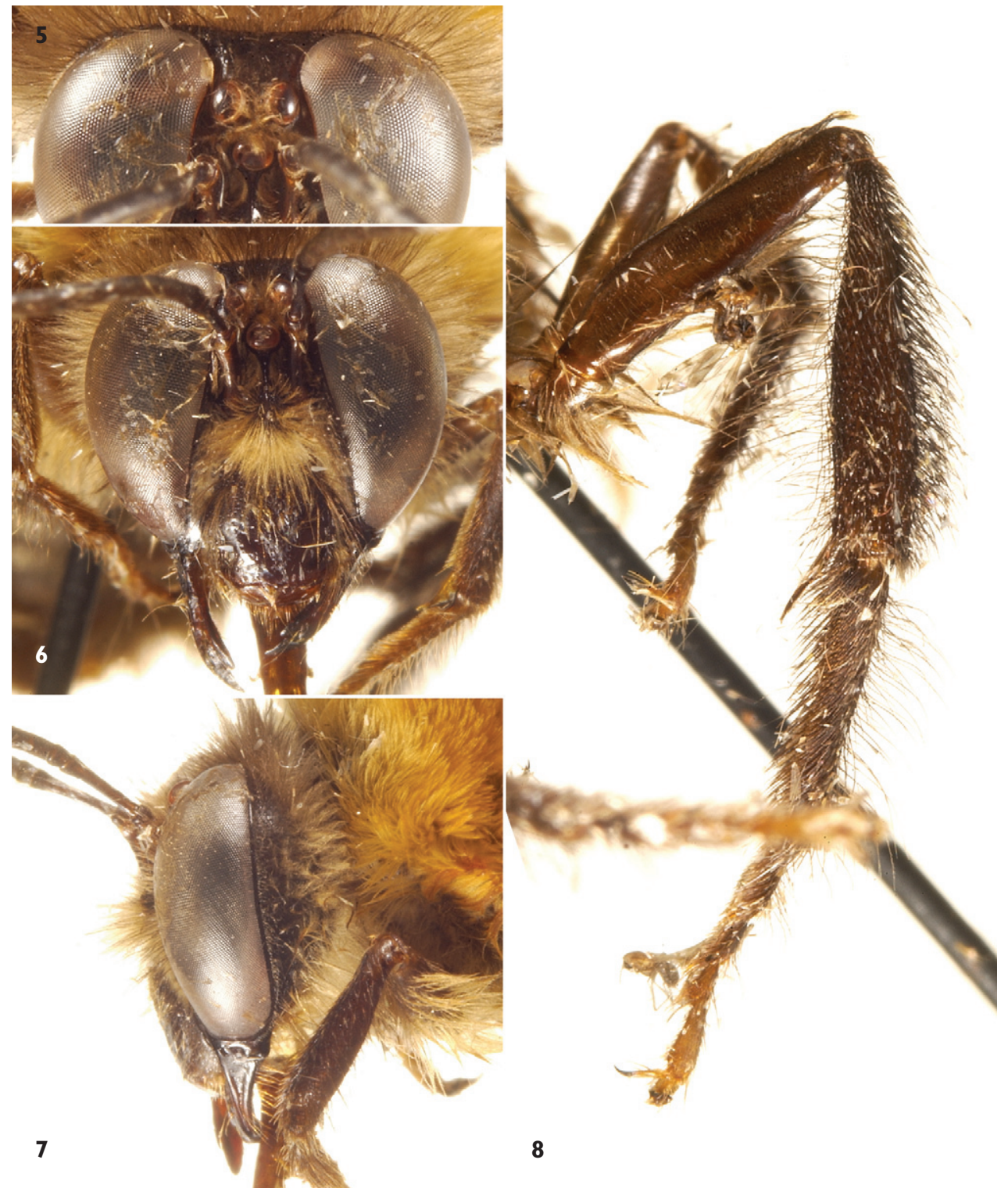

Figs. 5-8. Male of Caupolicana (Zikanapis) wileyi sp. n. 5) Ocellar view. 6) Facial view. 7) Lateral aspect of head. 8) Hind leg.

labrum with minor irregularities, not punctures. T5 and T6, except for smooth apical marginal zones, coarsely and rather closely punctate in contrast to preceding terga.

Integument black, under surface of flagellum dark brownish, particularly distally; small segments of tarsi brownish; pro- and mesofemora partly brown (note that the metabasitarsus is black, not yellowish as in C. inbio); posterior marginal zones of T5 and T6 translucent brown; ventrolateral dull areas of $\mathrm{T} 2$ to $\mathrm{T} 5$, and all sterna, largely brown. 

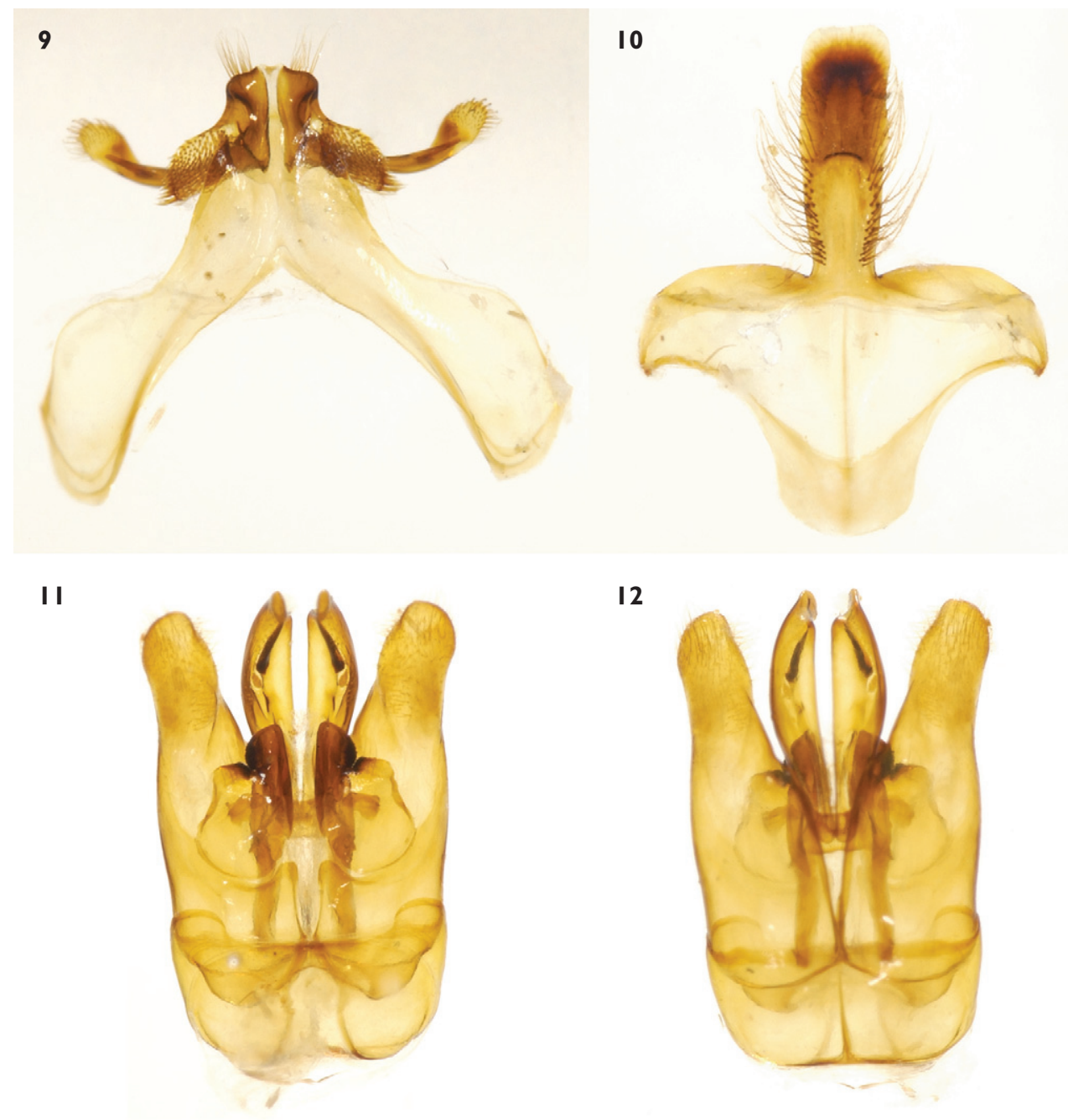

12

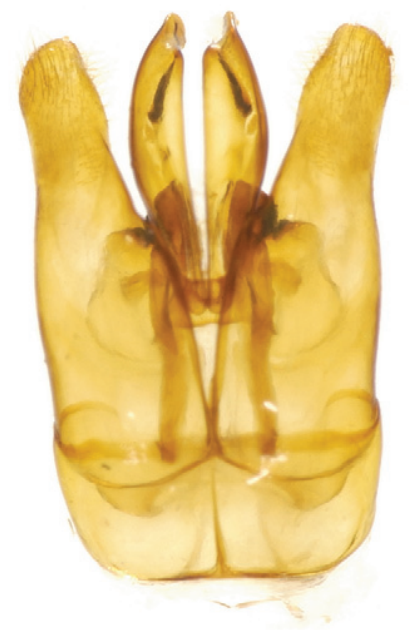

Figs. 9-1 2. Male terminalia of Caupolicana (Zikanapis) wileyi sp. n. 9) Seventh metasomal sternum. 10) Eighth metasomal sternum. 11) Genital capsule, ventral view. 12) Genital capsule, dorsal view.

Facial setae mixed ochraceous and black, mostly ochraceous on clypeus and lower supraclypeal area, which support long dense setae (Fig. 6); setae of vertex black, some black setae extending down along posterior orbit to middle or lower part of compound eye. Dense pile on mesosomal dorsum, uppermost mesepisternum, and T1 fulvous, often with irregular darker areas on posterior part of mesoscutum, apices of setae not blackish; setae of genal areas, ventral parts of head, sides (except above) and venter of mesosoma pale ochraceous, sometimes dusky in lower lateral and posterior parts of mesepisternum and blackish on anterior lateral parts of propodeum; pale ochraceous whitish on lower lateral and posterior parts of propodeum; setae of coxae to femora ochraceous and partly dusky; setae of meso- and metatibiae and tarsi dusky, partly 
ochraceous on under surface of midleg; setae of protibia and protarsus dusky to ochraceous. Setae of T1 whitish below laterally, but on dorsal surface fulvous as on mesosomal dorsum; setae of T2, T3, and intermixed on T4 black, dense, suberect (most nearly erect on T2), black or blackish setae continuing onto ventrolateral parts of terga and blackish on lateral extremities of sterna; otherwise sternal setae ochraceous; T4

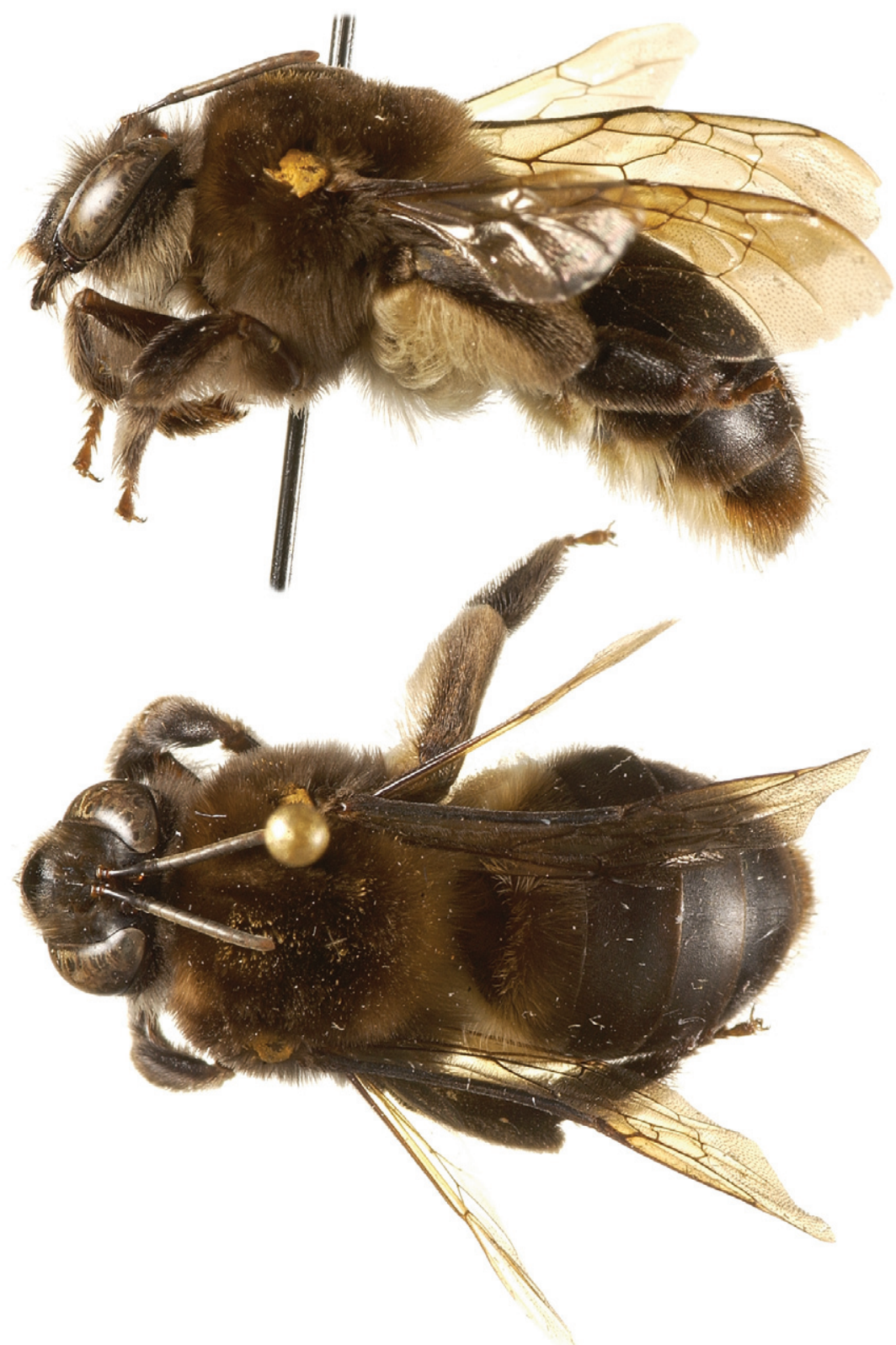

Fig. I3. Lateral (above) and dorsal (below) views of female of Caupolicana (Zikanapis) wileyi sp. n. 
with long setae mixed ochraceous and dusky; T5 to T7 with setae long, especially long on T5, ochraceous, slightly dusky especially laterally.

Female: Length $19 \mathrm{~mm}$; forewing length (including tegula) $15 \mathrm{~mm}$. Upper interorbital distance 3.2 OD; lower interorbital distance 4.9 OD; interocellar distance 0.7 OD; ocellocular distance $0.5 \mathrm{OD}$; ocelloccipital distance $0.5 \mathrm{OD}$; length of scape 2.2 OD. Structure otherwise as described for female C. inbio (Michener et al., 2003).

Densely punctate, dull part of clypeus occupying nearly upper third of clypeus except usually divided medially by extension of smooth surface upward from lower part of clypeus (Fig. 3); lower two thirds of clypeus except laterally smooth, shining, with few scattered large punctures.

Integument black, under side of flagellum brownish, especially distally, last flagellar segment brown beneath; tegula translucent infuscated testaceous; small segments of tarsi, especially distitarsi, brown; under surfaces of pro- and mesofemora and tibiae and sometimes metatibia and metabasitarsus partly brownish.

Setae of face dusky to blackish, areas of short dense pallid setae on frons and lower paraocular areas, longer setae of paraocular areas and setae of vertex black, black to dusky setae extending from vertex down along outer orbit to half or entire compound eye length, otherwise setae of gena and venter of head whitish. Pile of mesosomal dorsum, uppermost mesespiternum, and upper lateral surface of propodeum black or blackish, bases of setae often dusky; setae of mesepisternum laterally dusky, grading to pale dusky ventrally and on pro- and mesocoxae to femora, white or whitish on lower lateral surface and posterior surface of propodeum and on metacoxa to femur and under surface of metatibia; setae on outer surfaces of tibiae and basitarsi black, glistening pallid in some lightings; T1 with long setae whitish basally and laterally, dusky on posterior part of dorsal surface; dorsal surfaces of T2 and T3 with setae short, decumbent, dusky but glistening pallid in oblique light; T4 with similar setae but also scattered, long, erect whitish setae; T5 and T6 with abundant long pallid to coppery setae, a few of them dusky; lateral parts of terga with dusky to blackish setae, grading to yellowish white on ventrolateral extremities; sterna with setae yellowish white, whiter laterally.

Etymology. Caupolicana wileyi is so named in recognition of Dr. James R. Wiley of the Florida State Collection of Arthropods, who made possible this study by providing many of the specimens used.

\section{Acknowledgements}

We are grateful to James R. Wiley, Florida State Collection of Arthropods, for sending us over the years many interesting bee specimens, including Caupolicana. We are also grateful to Enio Cano for making available to us the Caupolicana from the collection at the Universidad del Valle de Guatemala, and to Jack C. Schuster for helping with this material. Partial support for this work was provided by US National Science Foundation grant EF-0341724 (to M.S.E.). 


\section{References}

Michener CD (1966) The classification of the Diphaglossinae and North American species of the genus Caupolicana (Hymenoptera, Colletidae). University of Kansas Science Bulletin 46(20): 717-751.

Michener CD (2007) The Bees of the World [2 $2^{\text {nd }}$ Edition]. Johns Hopkins University Press, Baltimore, xvi+[i]+953 pp.

Michener CD, Engel MS, Ayala R (2003) The bee genus Caupolicana in Central America (Hymenoptera: Colletidae). Journal of the Kansas Entomological Society 76(2): 160-171.

Moure JS (1945) Contribuição para o conhecimento dos Diphaglossinae, particularmente Ptiloglossa (Hym. - Apoidea). Arquivos do Museu Paranaense 4(6): 137-178, pl. xv.

Moure JS (1964) As espéces de Zikanapis, com a descrição de dois novos subgêneros e duas espéces novas (Hymenoptera, Apoidea). Studia Entomologica 7(1-4): 417-458. 